\title{
Status of Wetlands Supported by Agricultural Drainage Water in the Colorado River Delta, Mexico
}

\author{
Edward P. Glenn, Jaqueline Garcia, and Rene Tanner \\ Environmental Research Laboratory, 2601 East Airport Drive, Tucson, AZ 85706 \\ Chelsea Congdon and Dan Luecke \\ Environmental Defense Fund, 1405 Arapahoe Avenue, Boulder, CO 80302
}

\begin{abstract}
The delta of the Colorado River historically covered 780,000 ha in Mexico and the United States, encompassing most of what are now the Imperial, Mexicali, Yuma, and San Luis irrigation districts, as well as two below-sea-level depressions, the Salton Sea and Laguna Salada (Sykes, 1937) (Fig. 1). Before the 20th century, the lower delta was a vast network of riparian and wetland ecosystems in the most arid part of the Sonoran Desert (Leopold, 1949; McDougal, 1904; Sykes, 1937). Although most of the former wetlands and gallery forests have been converted to agricultural or urban use, there are still large wetland and riparian areas of conservation value in the lower delta in Mexico (Glenn et al., 1992, 1996; Morrison et al., 1996; Payne et al., 1992) (Fig. 1). Drainage water produced by horticultural industries in southwestern Arizona contributes to sustaining these ecosystems.

The remaining wetlands provide critical habitat for shorebirds and migratory waterfowl (Abarca et al., 1993; Mellink et al., 1997) and support the largest remaining populations of two endangered species, the desert pupfish (Hendrickson and Varela-Romero, 1989; Zengel and Glenn, 1996) and the Yuma clapper rail (Abarca et al., 1993;
\end{abstract}

Received for publication 4 Feb. 1998. Accepted for publication 4 Feb. The cost of publishing this paper was defrayed in part by the payment of page charges. Under postal regulations, this paper therefore must be hereby marked advertisement solely to indicate this fact.
Eddleman, 1989). The indigenous Cocopa people still use the riparian zone of the delta for subsistence (Richardson and Carrier, 1992; Williams, 1983), and the wetlands and reforested areas provide incomes to ejido residents who gather fuelwood and serve as guides to hunters, fishermen, and ecotourists (Payne et al., 1992). In recognition of their importance, portions of the delta wetlands were incorporated into La Biosfera del Alto Gulfo de California y el Delta del Rio Colorado, an international biosphere reserve recognized by the United Nations international biosphere program and declared by President Salinas of Mexico in 1993 (Diario Oficial, 1993; Morales-Abril, 1994).

The remaining wetlands are a collection of natural and anthropogenic marshes, supported by tide water, artesian springs, and agricultural drainage water. The wetlands are greatly impacted by water management decisions in the United States and Mexico. The safety of the wetlands for wildlife is dependent upon the water quality of the inflow waters. Until recently, however, they have not been managed or protected. With the creation of the biosphere reserve, international interest in preserving the delta wetlands has developed (Congdon and Luecke, 1996; Morrison et al., 1996). Furthermore, since Lake Powell filled in 1981, occasional flood flows are again a feature of the lower Colorado River, providing an augmented water supply that has reforested much of the river floodplain (Glenn et al., 1996). 


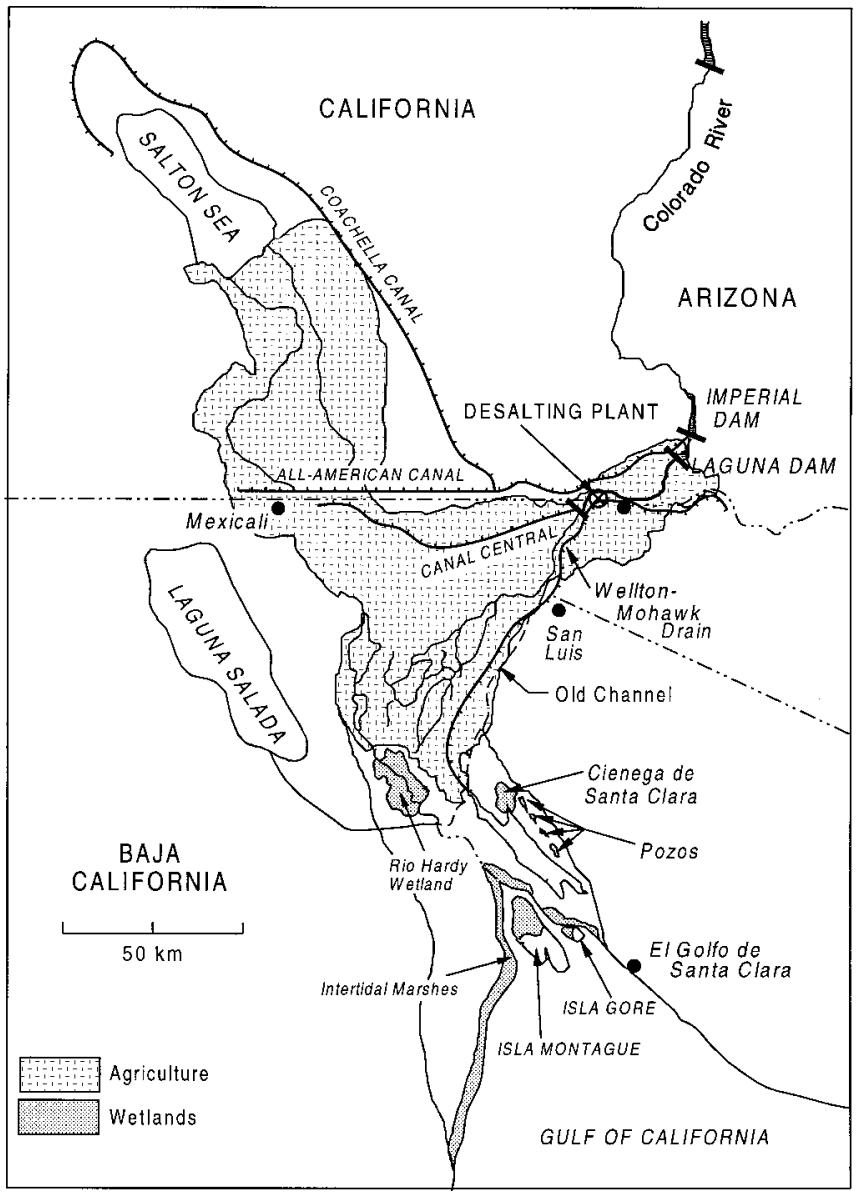

Fig. 1. Main features of the Colorado River delta in the United States and Mexico, including the wetland areas below the agricultural fields in Mexico.

We will describe the major natural and anthropogenic wetlands and their water sources, and point out problems and opportunities in converting the transient wetlands into sustainable environmental assets for the region. The riparian vegetation in the main channel of the Colorado River in Mexico is treated elsewhere (Valdes-Casillas et al., 1998). If the currently available water supplies to the lower delta were managed for maximum impact they could support up to 60,000 ha of wetlands and riparian forests, yet in 1996 there were <6000 ha of such areas remaining. The steps needed to improve the situation are outlined.

\section{WETLANDS OF THE COLORADO RIVER DELTA}

The natural wetlands: intertidal salt marshes. The natural wetlands are the salt marshes in the intertidal zone and the pozos, or freshwater springs, in the eastern delta. The intertidal wetlands are flooded by the large daily tides of the upper Gulf of California, typically $3 \mathrm{~m}$ in amplitude (Thompson, 1968). They fringe the southern shores of the delta and partially cover the two large islands at the mouth of the Colorado, Isla's Montague and Gore (also called Isla Pelicano) (Fig. 2). The marsh vegetation is restricted to a dozen halophyte species that can survive the hypersaline $\left(>40,000 \mathrm{mg} \cdot \mathrm{L}^{-1}\right)$ seawater of the upper gulf. They are dominated by an endemic saltgrass, Distichlis palmeri (Vas.) Fassett, which produces an edible grain that was harvested by the indigenous Cocopa people up to the 20th century (Kniffen, 1931).

There are $\approx 33,000$ ha of $D$. palmeri marshes in the delta (Glenn et al., 1996). They are feeding stations for birds that prey upon the crabs and small fish that inhabit the marshes, and are nursery areas for the juvenile stages of fish and crustaceans. They help support the food chain upon which the endangered vaquita porpoise (Morales-Abril,
1994) and totoaba fish (Cisneros-Mata et al., 1995) depend. The intertidal wetlands were more extensive and more vigorous when they received regular summer freshwater floods from the Colorado River (Sykes, 1937). Floods in 1983 and 1993 markedly, though temporarily, improved the condition of the marshes, judging by the extent of salt marsh area and infrared reflectance in satellite imagery from different years (Glenn et al., 1996). The offshore fisheries also reportedly improved after those floods (Morrison et al., 1996).

Pozos. The pozos (wells) are small, pocket wetlands formed by artesian water bubbling onto the mudflats. They are found mainly along the eastern escarpment where the sand dunes of the Gran Desierto intersect the intertidal zone, but they also occur in the Bahia Adair estuary south of the delta (Ezcurra et al., 1988). The pozos are fed by ground water from the Gran Desierto emerging onto the mud flats; they form a discontinuous line of vegetation at the edge of the escarpment, but isolated pozos occur $1 \mathrm{~km}$ or more out on the flats. Near the escarpment the pozos are dominated by Prosopis glandulosa Torr. (mesquite) while further out on the flats they are dominated by Typha domingensis Pers. (cattail) and Scirpus americanus Pers. (bulrush), and support two dozen other wetland species. Where the water bubbles to the surface, freshwater species dominate, but as the water spreads over the intertidal mud it becomes saline, so the fringes of the pozos are dominated by halophytes.

We estimate that there are $<500-750$ ha of pozos in the delta (Glenn et al., 1996). They have the greatest diversity of aquatic plants of any of the delta wetlands since they are supported by fresh water (Zengel et al., 1995). The main threat to the pozos is overgrazing by cattle; most of the accessible vegetation has been grazed to near ground level and only the larger pozos, with enough standing water to prevent entry of cattle, have well-developed canopies (Glenn et al., 1996).

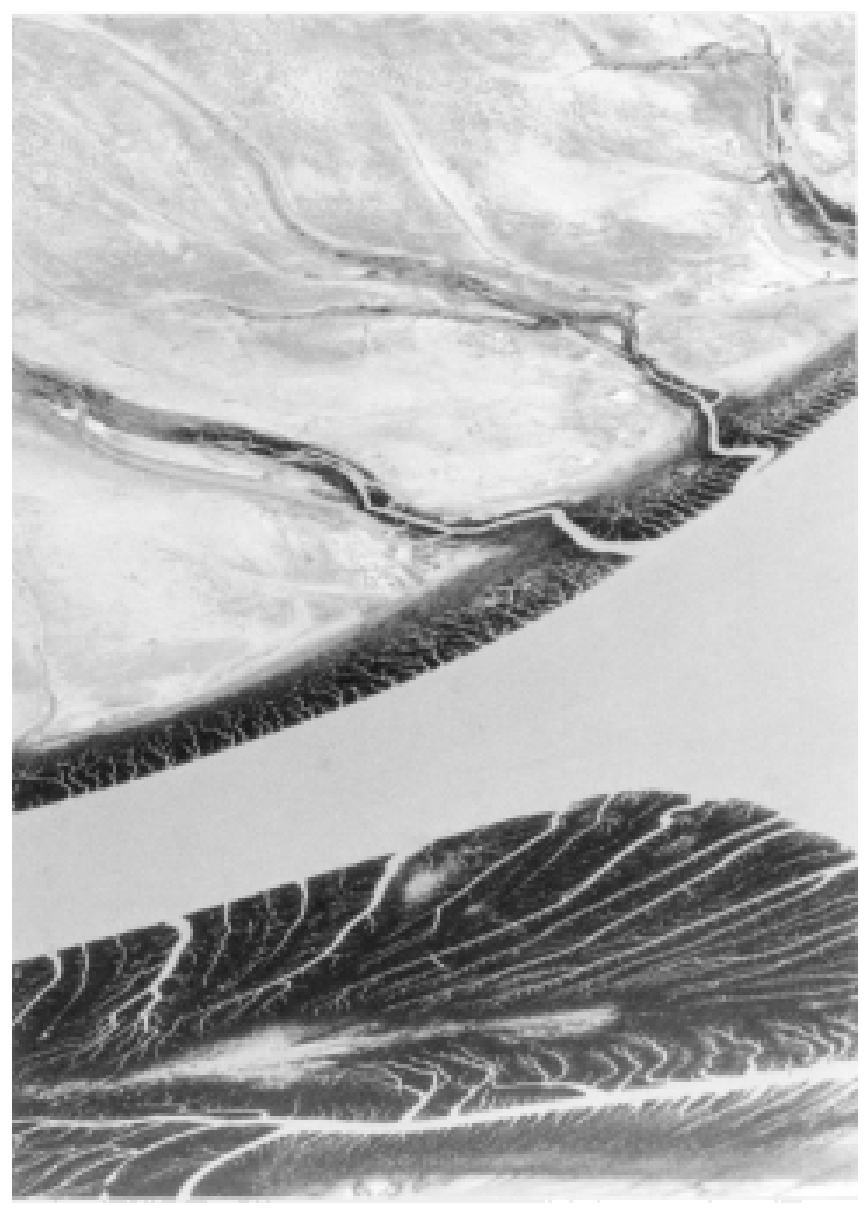

Fig. 2. Palmer's grass (Distichlis palmeri) in intertidal salt marshes on Isla Montague (top of photo) and along the banks of the Colorado River near the mouth. The photograph was taken at low tide. At high tide all the land visible in the photograph is submerged. 
Anthropogenic wetlands. Two wetlands-Cienega de Santa Clara on the eastern side of the delta and the Rio Hardy wetland in the westcontain most of the potential brackish (3000-5000 $\left.\mathrm{mg} \cdot \mathrm{L}^{-1}\right)$ aquatic habitat in the delta. These marshes are partly natural and partly manmade. In their natural state they were supported by freshwater flow in the Colorado River, but are now sustained by the disposal of brackish agricultural drainage water into the lower delta, plus occasional flood flows. Until recently they have been unmanaged and have undergone large changes in area over the past 25 years (Table 1) (Glenn et al., 1996).

Cienega de Santa Clara. This is currently the largest brackish wetland in the delta and has been included in the core zone of the Biosphere Reserve because of its importance in supporting waterfowl and endangered bird and fish species. It is a $4400 \mathrm{ha}$, thickly vegetated T. domingensis marsh that provides the most important waterfowl habitat along the lower Colorado River (Abarca et al., 1993; Eddleman, 1989) (Fig. 3). The Cienega is in a natural depression formed by the Cerro Prieto fault, a branch of the San Andreas fault line that enters the Gulf of California near the town of Santa Clara (Burnett et al., 1993). Before the construction of Hoover Dam it was a vegetated, overflow arm of the Colorado River (Sykes, 1937), but with the cessation of floods it retreated to a small marsh of several hundred ha, fed by springs and local irrigation drainage (U.S. Bureau of Reclamation, 1975).

It was reflooded starting in 1977. The main water source supporting the Cienega de Santa Clara is saline, subsurface drainage water pumped from beneath the Wellton-Mohawk irrigation district in the United States (Glenn et al., 1992). It is conveyed to the Cienega in a lined, $80 \mathrm{~km}$ canal, the Main Outlet Drain Extension (M.O.D.E.). The Wellton-Mohawk district is on the Gila River upstream from its junction with the Colorado River. It is irrigated with Colorado River water but has a perched, saline water table that is controlled by wells discharging water of $\approx 3000 \mathrm{mg} \cdot \mathrm{L}^{-1}$ total dissolved solids (TDS) into the M.O.D.E. canal. The Cienega also receives local agricultural drainage water of $4000 \mathrm{mg} \cdot \mathrm{L}^{-1}$ salt content via the Riito canal.

The Cienega de Santa Clara continues to be investigated by the U.S. Bureau of Reclamation as a possible disposal site for brine from the Yuma Desalting Plant, which would process water from the M.O.D.E. canal (Glenn et al., 1992). Full operation of the plant would reduce the inflow volume into the Cienega by $65 \%$ and increase the salinity to above $7 \mathrm{mg} \cdot \mathrm{L}^{-1}$ TDS, which exceeds the tolerance limit of the dominant vegetation (Burnett et al., 1993; Glenn et al., 1995; Zengel et al., 1995). An evapotranspiration model (Tanner et al., 1997) was developed from published data (Burnett et al., 1993; Glenn et al., 1995) to predict the effects of salinity increase and flow reduction on the area covered by $T$. domingensis in the Cienega. Based on an annual flow in the M.O.D.E. of $1.4 \times 10^{8} \mathrm{~m}^{3}$ at $3200 \mathrm{mg} \cdot \mathrm{L}^{-1}$ TDS (U.S. Bureau of Reclamation, 1990), the model predicts that even one-third plant operation would reduce the vegetation coverage by $46 \%: 22 \%$ due to salinity increase and $24 \%$ due to flow reduction. The reduced vegetation area would probably impact the endangered species (Yuma clapper rails and desert pupfish) and other wildlife in the Cienega.

Rio Hardy wetlands. During the 1970s, the Rio Hardy wetlands on the western side of the delta contained 15,000 to 20,000 ha of brackish marshes below the junction of the Colorado River and the Hardy River (Fig. 4). The wetland was home base for the Cocopas who hunted, fished, and guided tourists in the rivers and marshes. The wetlands were supported by agricultural drainage water from Mexicali Valley

Table 1. Estimated mean water flows and salinities into the lower delta wetlands, 1980-96. Discharge points are the Gulf of California at the mouth of the Colorado River, the Cienega de Santa Clara or the artesian springs along the eastern escarpment of the lower delta.

\begin{tabular}{lccl}
\hline \hline Source & $\begin{array}{c}\text { Flow/year } \\
\left(\text { billion } \mathrm{m}^{3}\right)\end{array}$ & $\begin{array}{c}\text { Salinity } \\
\left(\mathrm{mg} \cdot \mathrm{L}^{-1}\right)\end{array}$ & Discharge point \\
\hline Colorado River & 5.2 & $<1000$ & Gulf \\
Rio Hardy & 0.5 & 4200 & Gulf \\
M.O.D.E. & 0.15 & 3000 & Cienega \\
Riito & 0.03 & 4000 & Cienega \\
Pozos & 0.01 & 1000 & East escarpment \\
& Sum: 5.89 & Mean: 1300 & \\
\hline
\end{tabular}

carried to the Gulf of California in the Rio Hardy and Colorado River. A natural sand bar in the Colorado River channel $\approx 35 \mathrm{~km}$ from the mouth impounded water in the wetland. The water contains $\approx 4000$ $\mathrm{mg} \cdot \mathrm{L}^{-1}$ salts (Payne et al., 1992; Velez et al., 1978).

In 1983-86, floods in the Colorado River greatly expanded the Rio Hardy wetland area (Fig. 4). They also allowed the reestablishment of cottonwood poplar (Populus fremontii S. Wats.) and willow (Salix gooddingii Ball) thickets. These now occur in isolated, multi-acre stands to 10-m height, overtopping the dominant tamarisk (Tamarix ramosissima Ledeb.) along the mainstream of the Colorado River from the northern international border to the junction of the Colorado and Rio Hardy, and creating a riparian zone 100 km long (authors' personal observations, 1997). The forested riparian zone is maintained by occasional flood releases such as the one in 1993 (Glenn et al., 1996) and 1997. However, the floods also breached a natural dam that held the water in the area, and, when the flood waters recede, the Rio Hardy marshes drain to <1000 ha (Fig. 4) (Glenn et al., 1996).

\section{WATER SOURCES IN THE LOWER DELTA}

Although the popular perception is that water no longer reaches the delta and Gulf of California (Fradkin, 1981; Richardson and Carrier, 1992), over the past 15 years (1981-96) the mean annual flow of all water sources into the delta wetlands averaged 6 billion $\mathrm{m}^{3}, \approx 25 \%$ of the total river flow during those years (Table 1). The weighted mean salinity was low, $1300 \mathrm{mg} \cdot \mathrm{L}^{-1}$. These mean values, however, obscure the erratic nature of the flows, outlined below.

Agricultural drainage and artesian water. Since 1977 the M.O.D.E. canal has carried 120-180 million $\mathrm{m}^{3}$ of subsurface drainage to the Cienega de Santa Clara (Burnett et al., 1993). The Riito canal has carried $\approx 25$ million $\mathrm{m}^{3}$ of San Luis agricultural drainage (Burnett et al., 1993). We do not have accurate information on flows in the Rio Hardy. Velez et al. (1978) reported that the river carried $\approx 130$ million $\mathrm{m}^{3}$ of Mexicali Valley drain water in 1976, with an equal volume going north to the Salton Sea. The estimate by Velez et al. (1978) did not include geothermal or nonpoint source discharges from surrounding fields into the marshes or artesian springs on the western side of the delta. Based on the area of the wetland visible in 1973 satellite images (18,000 ha) and annual evapotranspiration estimates for Cienega de Santa Clara (Burnett et al., 1993; Glenn et al., 1996), as much as 500 million $\mathrm{m}^{3}$ per year of water may have entered the western marshes in the 1970s. The artesian springs along the eastern escarpment added another 10 million $\mathrm{m}^{3}$ of low-salinity water to the delta (Glenn et al., 1995). Summing up all sources, the total annual flow of agricultural drainage and artesian water into the delta is $\approx 700$ million $\mathrm{m}^{3}$ per year, but better data on these flows are needed.

Floodflows. In addition to the above sources, the delta occasionally receives large flood flows released from the upstream impoundments. Data for the flow of water into the delta wetlands (below the last diversion point for agriculture) from 1905 to 1996 (Fig. 5) indicate a diminishing trend. There was no flow at all in the main stem of the Colorado River to the delta wetlands from 1962 to 1980, while Lake Powell, behind Glen Canyon Dam, the last major impoundment built on the river, was filling. Thereafter the treaty allotment (10\% of base flow) crossed the border to be used for irrigation. Since 1983, however, there have been large releases of water to the delta. The 1980-87 releases were from impoundments on the Colorado River, but the 1993 spike was from Painted Rock Reservoir on the Gila River. The flood releases over the last 15 years (above the treaty allotment to Mexico) have averaged $\approx 5.2$ billion $\mathrm{m}^{3}$ per year.

\section{POTENTIAL FOR WETLAND RESTORATION IN THE DELTA}

Based on evapotranspiration estimates for Cienega de Santa Clara (Burnett et al., 1993; Glenn et al., 1995), the total annual flows (Table 2 ) could support $\approx 200,000$ ha of wetland if all the water were consumed in evapotranspiration. However, due to salinity constraints (Glenn et al., 1995) a more reasonable projection is that half the water would be consumed in evapotranspiration and half would exit the wetlands into the Gulf of California, reducing the potential wetland 


\section{WORKSHOP}

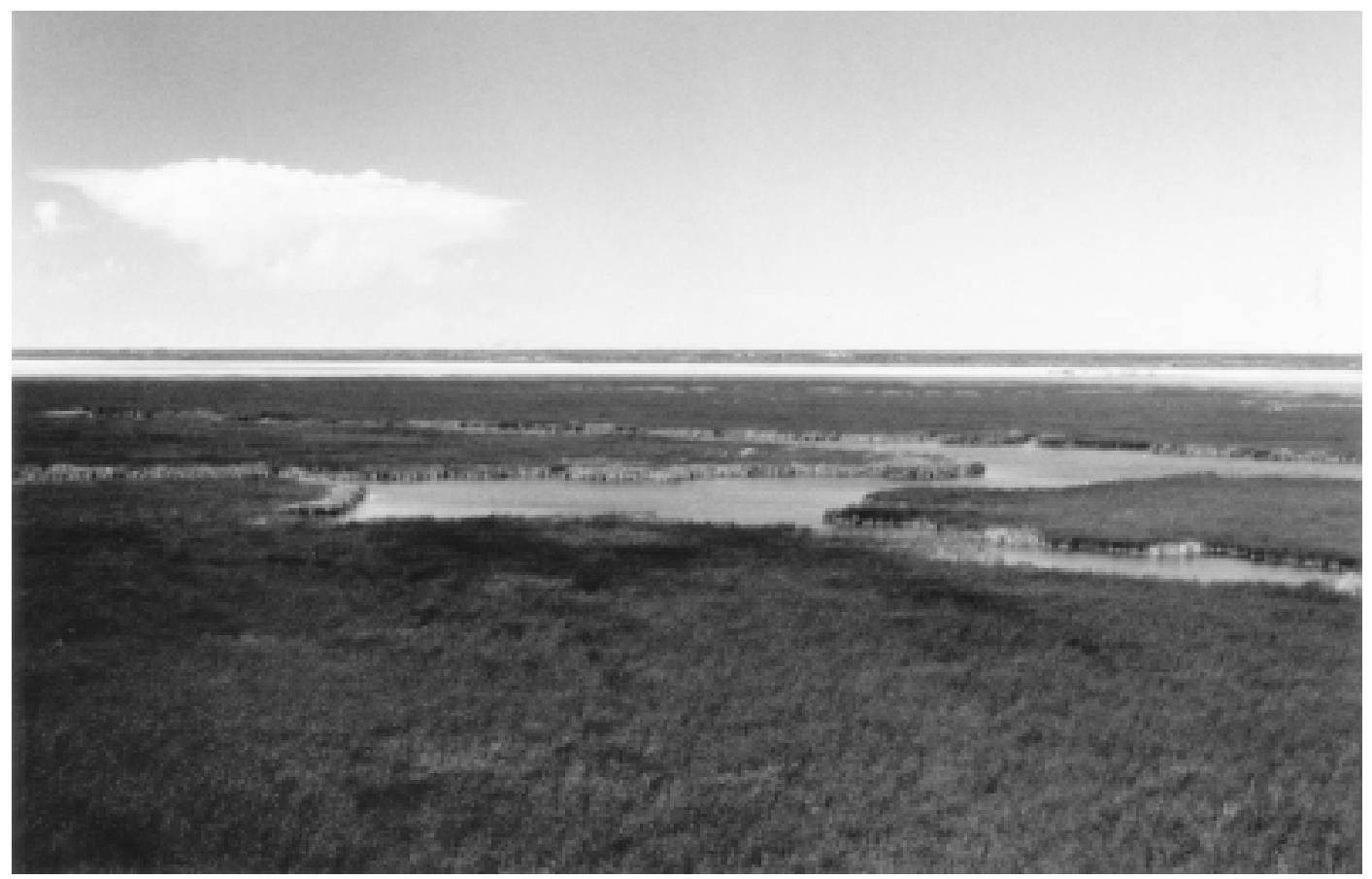

Fig. 3. Aerial view of part of the Cienega de Santa Clara, Mexico. The vegetation is mainly cattail (Typha domengensis), 2-3 $\mathrm{m}$ in height. The marsh contains numerous open areas, such as the one illustrated, that are feeding stations for birds.

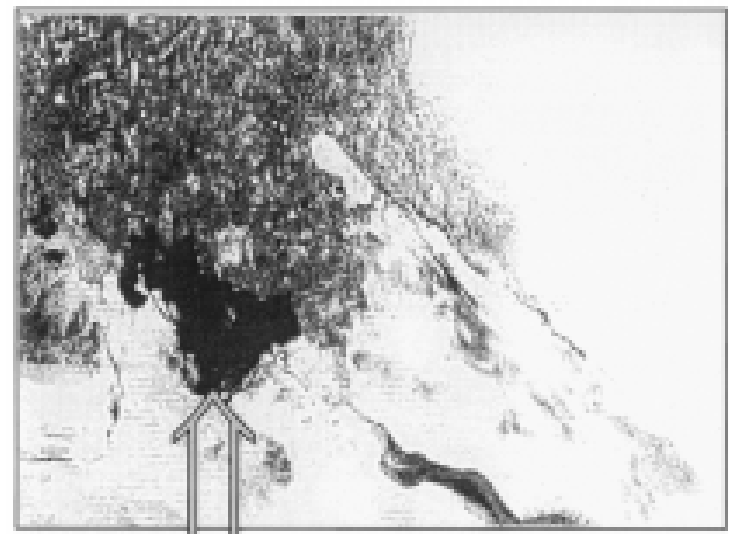

$\overline{10 \mathrm{~km}} 1973$

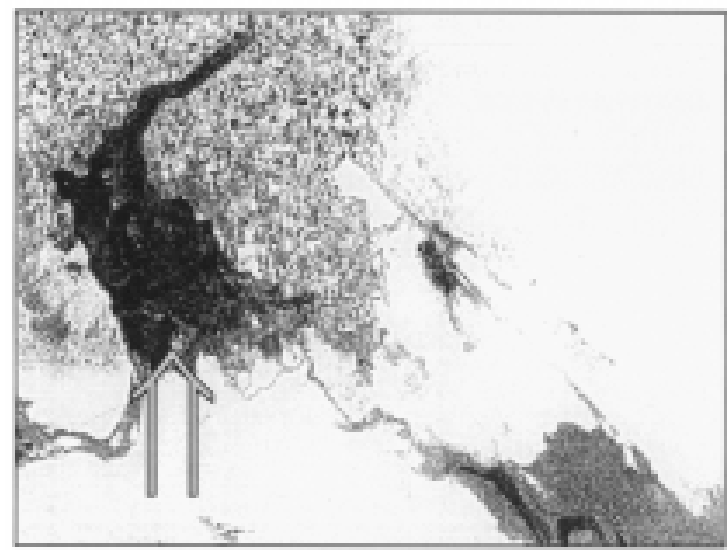

$\overline{10 \mathrm{~km}} 1986$

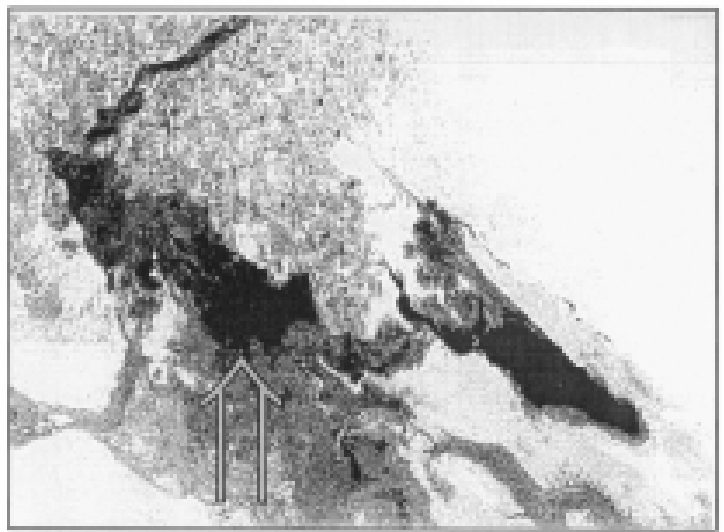

$\overline{10 \mathrm{~km}} 1983$

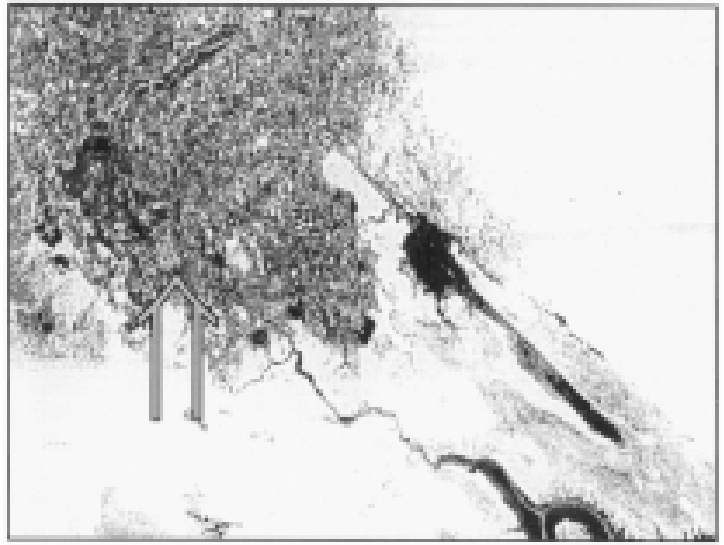

$\overline{10 \mathrm{~km}} 1999$

Fig. 4. Multispectral scanner satellite images of the lower Colorado River delta in 1973, 1983, 1986, and 1988, showing changes in the size of the Rio Hardy wetland (arrow). Wetland areas and shallow standing water are dark. Agricultural fields appear as squares or rectangles in the northwest quadrant of each image. The entry point of the Colorado River into the Gulf of California is in the southeast quadrant. White areas are the Gran Desierto River in the east and mud and salt flats of the delta in the southwest quadrants. 
area to 100,000 ha. This scenario would allow $\approx 3$ billion $\mathrm{m}^{3}$ per year to flow into the Gulf of California, enriching the marine environment. Following the 1983 floods the delta supported up to 60,000 ha of vegetation, not including Laguna Salada (Glenn et al., 1996), which may be close to the maximum achievable wetland area based on land availability.

The flood releases of the 1980 s were unusually high, attributed to El Niño weather conditions and aberrations in the operation of the dam system, which had never before been filled to capacity (Holburt, 1982, 1984; U.S. Bureau of Reclamation, 1990). The Bureau of Reclamation cannot predict future releases, but it does confirm that occasional flood releases will become part of the management strategy for the river, because the dams are designed to be kept nearly full both for maximum efficiency in generating hydroelectric power and to capture and distribute as much as possible of each year's snowmelt in the watershed. During wet years, excess flows will be released to the delta (Don Young, U.S. Bureau of Reclamation, private communication; Holburt, 1982, 1984; U.S. Bureau of Reclamation, 1990). From 1951 to 1961, excess flows released from Hoover Dam averaged 2.9 billion $\mathrm{m}^{3}$ per year (Morrison et al., 1996) (Fig. 5). If future flood flows are similar to these, the area of wetland that could be supported is $\approx 60,000$ ha, or the amount actually present in 1983 . Hence, shortage of land rather than water may become the limiting factor for how much wetland area can be restored in the delta.

During a series of normal or dry years there are no flood flows, and the wetland area will inevitably retreat to what can be sustained by agricultural drainage water. These sources can support core wetland areas of about 22,000 ha. Due largely to the draining of the Rio Hardy wetlands, the actual brackish wetland area in the delta was only 6,000 ha by 1996. At the present time the area of reforested riparian habitat has not been accurately estimated.

\section{OBSTACLES TO CONSERVATION}

Lack of information. The first problem facing wetland restoration is the lack of information on the historical and current resources of the delta. Taking restorative action in an information vacuum is difficult. The only thorough study of the delta was the personal observations of Sykes between 1891 and 1935 (Sykes, 1937). Recently, the Cienega de Santa Clara has received attention, with studies published on the birds and fish (Abarca et al., 1993; Eddlemen, 1989; Zengel and Glenn, 1996), hydrology (Burnett et al., 1993), and vegetation (Glenn et al., 1995; Zengel et al., 1995). The time course of vegetation development in the Cienega after water disposal began in 1977 has been recreated through satellite images (Lee, 1994). A management plan has been developed for the Cienega and a check list of birds and fish is being compiled (Jose Campoy, private communication). However, we have found no studies describing the water quality, vegetation, flora, and human uses of the Rio Hardy wetlands when they were full prior to 1986. None of the wetlands of the delta, natural or man-made, are accurately depicted on topographic maps of the area.

Lack of management. Prior to declaration of the biosphere reserve in 1993 the delta wetlands received no explicit management or even recognition from the United States or Mexico. Since they are below the agricultural fields, they do not directly impact the irrigation districts and are not taken into account when water management decisions are made. The Cienega de Santa Clara was an accidental creation of water disposal and it will be severely damaged if the water supply is diverted to the Yuma Desalting Plant and replaced by brine, as was the original intention (Glenn et al., 1992; Morrison et al., 1996). The Rio Hardy marshes, which were inadvertently drained, have not been restored despite a 1992 proposal by Ducks Unlimited to replace the natural sand bar with a man-made structure for $\$ 250,000$ (Payne et al., 1992). Some of the intertidal wetlands have been dredged to develop tourist facilities on the western side of the delta, while a large shrimp farm has damaged the D. palmeri marshes on the eastern shore. The pozo wetlands are trampled and overgrazed by cattle. Large sections of riparian forest habitat have been burned by residents, or cleared by irrigation district engineers to improve stream flow during floods.

Hazards from selenium and other toxic elements. Currently, the use of agricultural drain waters to support wetlands is considered problem-

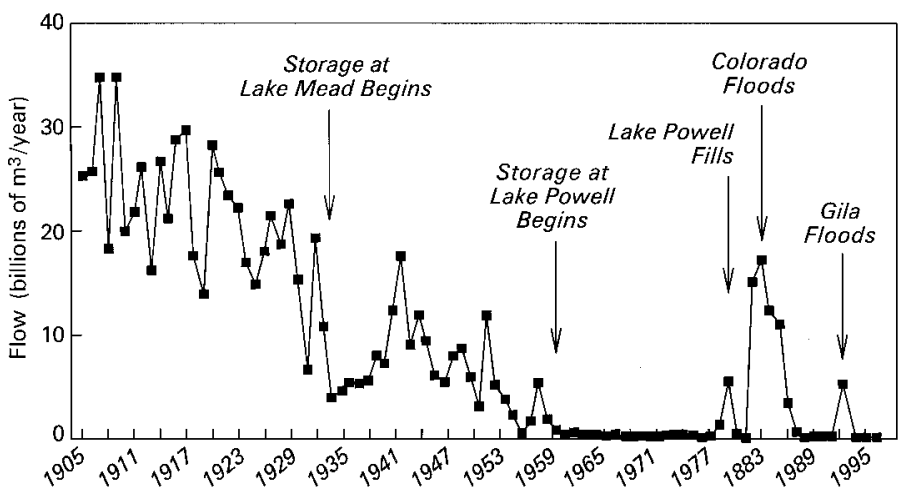

Fig. 5. Flow of the Colorado River into the delta wetlands, below all major dams and diversions, 1905-96 [from information in Glenn et al. (1996) and Morrison et al. (1996)]. Arrows show important events that impacted the flow.

atic due to toxicity problems that have developed, particularly with selenium, which is present in many western soils (Skorupa and Ohlendorf, 1991). Agricultural drainage water leaches selenium and other contaminants from the soil, and selenium can subsequently accumulate in wetland food chains and can cause death or deformity to fish, waterfowl, and other wetland fauna (Hotham and Ohlendorf, 1989). Selenium toxicity has so far only been consistently documented in the closed discharge basins used for agricultural drainage disposal in the Westlands area of the San Joaquin Valley (Hotham and Ohlendorf, 1989; Ong et al., 1995; Presser, 1994; Young and Congdon, 1994). However, elevated selenium levels have also been documented in many habitats along the lower Colorado River (Lusk, 1993; Martinez, 1994; Rusk, 1991; U.S. Geological Survey, 1988; Welsh, 1992). Therefore, the use of agricultural drainage water to support wetlands must be approached with caution. Selenium buildup can conceivably be prevented in the delta wetlands by using the tides and flood flows as flushing agents. This hypothesis can be tested by analyzing selenium levels in the water, soil and biota of the existing wetland areas such as Cienega de Santa Clara and the remaining portions of the Rio Hardy wetlands before beginning restoration projects.

Consequences of dwindling water supplies and lack of management. In 1996 the area of brackish delta wetlands was at a 25 year low (Table 2). If the Rio Hardy wetlands are not restored, and if the Cienega de Santa Clara is diminished by diverting M.O.D.E. water to the Yuma Desalting Plant, the area of brackish wetland could decrease to $<2,000$ ha in the near future. This would be a severe loss, as the delta contains the largest and most important wetland areas in the Sonoran desert.

\section{STEPS TOWARD RESTORING THE DELTA WETLANDS}

Scientists and environmental groups are attempting to fill the information gap through studies on current and historic conditions of ecological, cultural, and economic values in the delta wetlands; the effects of modified flow patterns; water chemistry concerns; and the effect of freshwater flows on the marine ecosystem. These studies are supported and conducted by private and public institutions on both sides of the border (Congdon and Luecke, 1996). Funding sources include the National Wetlands Council of the U.S. Fish and Wildlife Service, the Bureau of Reclamation, the Environmental Defense Fund, the Pacific Institute, and others. A database on delta environmental studies is being compiled for the Environmental Protection Agency (M. Nechodorn, Lower Colorado River Study, Univ. of California at Davis). The results of these studies, compiled in GIS and other formats, will provide the basis for assessing alternative management and restoration strategies for the wetlands.

Some management changes are already under way. With creation of the biosphere reserve, the delta wetlands are now receiving management attention. Mexico completed a comprehensive management plan that includes the following goals: preservation of the ecosystems of the delta; establishment of permanent areas for protection of endangered species; promotion of economic and administrative activities that 
Table 2. Estimates of wetland vegetation (ha) in the Colorado River delta, based on satellite images. Area of intertidal marsh remained constant at 33,000 ha.

\begin{tabular}{|c|c|c|c|c|}
\hline \multirow[b]{2}{*}{ Year } & \multicolumn{4}{|c|}{ Fresh or brackish marsh } \\
\hline & Rio Hardy & $\begin{array}{l}\text { Cienega de } \\
\text { Santa Clara }\end{array}$ & El Doctor & Total \\
\hline$\overline{1965}$ & $\mathrm{n} / \mathrm{a}$ & $\mathrm{n} / \mathrm{a}$ & $\mathrm{n} / \mathrm{a}$ & \\
\hline 1973 & 18,000 & 200 & $500-750$ & 18,825 \\
\hline 1983 & 60,000 & 2,500 & $500-750$ & 63,125 \\
\hline 1986 & 38,000 & 3,600 & $500-750$ & 42,225 \\
\hline 1988 & 1,300 & 4,500 & $500-750$ & 5,800 \\
\hline 1993 & 24,000 & 1,400 & $500-750$ & 26,025 \\
\hline 1996 & 1,000 & 4,500 & $500-750$ & 5,500 \\
\hline
\end{tabular}

increase the quality of life in communities in the region; support for scientific investigation and environmental education; and recovery and preservation of flora, fauna, and other environmental resources in the region (Jose Campoy, private communication). The U.S. Bureau of Reclamation has recognized the need for replacement water for the Cienega de Santa Clara if the Yuma Desalting Plant is operated (Burnett et al., 1993).

These developments are important first steps in what must be a binational program for protecting and enhancing critical estuarine and riparian resources that support migratory and resident waterfowl (Mellink et al., 1997), fisheries, endangered species, and human populations in the region. There is growing international interest among state, local, and regional governments from both countries, resource agencies, nongovernmental organizations, researchers, and educators in finding cost-effective and feasible solutions.

A recent workshop organized by the Environmental Defense Fund to define water supply options for wetlands restoration was attended by the Commissioners of the International Boundary Water Commission in the United States and the Comision Internacional de Limites y Aguas in Mexico, representatives of all the implementing agencies, and scientists and environmentalists from both sides of the border (Congdon and Luecke, 1996). The consensus of the workshop was that the delta wetlands are important environmental assets for both nations and they will be taken into account in future water management decisions. Specifically, participants in that workshop and, more recently, a proposal by Instituto Nacional de Ecologia in Mexico, discussed a number of water supply options for the delta.

One option is to manage residual flows that now reach the wetlands but are not delivered or managed in any deliberate way. This is particularly true for the Cienega de Santa Clara wetlands where drainage deliveries could guarantee a water supply to the area. Other sources include coordinated management of flood releases from upstream dams and reservoirs that could help restore the delta habitats through carefully timed spike flows (similar to the recent experimental spike flow release from Glen Canyon Dam) that redistribute sediment and flush important backwater areas. In addition to engineering and management measures to control drainage and flood flows, there are options for augmenting supplies of water to the delta from sources within Mexico and the United States. Among these potential sources, treated municipal wastewater from Mexicali and San Luis Rio Colorado might be used to restore delta wetlands. In addition to helping restore the Rio Hardy wetlands, treated wastewater also could be used to augment irrigation supplies in the western part of the Mexicali Valley. Finally, while states within the Colorado River basin have begun to experiment with water marketing and water banking arrangements, very little consideration has been given to the potential for voluntary transfers of water across the international border.

\section{THE DELTA WETLANDS AS PART OF THE REGIONAL ECOSYSTEM}

The delta wetlands are part of the larger regional ecosystem, including the Sonoran desert to the east and west, and the agricultural and horticultural areas of the Mexicali, San Luis, Yuma, and Imperial valleys. They are part of the Pacific flyway and provide critical aquatic wildlife habitat for this desert region. The lower delta is connected to the Salton Sea by the Alamo and New River riparian corridors, and there are proposals to restore these degraded habitats (Walker and
Forrest, 1996). Currently most of the region's agricultural and municipal drainage water from both Mexico and the United States drains to the Salton Sea, which is becoming hypersaline $\left(45,000 \mathrm{mg} \cdot \mathrm{L}^{-1} \mathrm{TDS}\right)$ (Black, 1983; Boyle, 1996), eutrophic from excess nutrient input (Setmire, 1984), and potentially toxic to fish by the evapoconcentration of selenium (Matsui et al., 1992) and other elements of concern (Boyle, 1996).

The delta wetlands should be viewed as part of a regional system for handling wastewater and flood flows for maximum benefit for, and minimum risk to, wildlife and human health. The delta wetlands can be managed as a flow-through system, flushed by tides and periodic flood flows. With water from these sources to maintain core ecosystems, the wetlands can be expanded when flood flows are available. These improvements can be coordinated with and complement the ongoing efforts to manage marine ecosystems and fisheries as part of the biosphere reserve to enhance the nursery, feeding, and breeding habitats in the near-shore areas. However, the opportunities for augmenting riparian and wetland habitats in the lower delta should be developed as part of an overall plan that deals with the problems of the Alamo and New River corridors and the Salton Sea as well. A consortium of county and local governments, resource agencies, and irrigation districts in California has examined a number of options for stabilizing water quality and elevation of the Salton Sea, while minimizing threats to wildlife (Salton Sea Authority, 1997). One proposal would connect the Salton Sea to the upper Gulf of California to provide flushing for that water body as well (Patrick J.A. Quinlan, Office of Congressman George E. Brown, Jr., unpublished document, 1997), although this would be expensive and the environmental risks are unknown (Salton Sea Authority, 1997). The analysis of what to do about the Salton Sea needs to consider the effects of such actions on the delta wetland, riparian and marine ecosystems in Mexico, to be sure that the problem is not simply transferred rather than solved. At present the delta wetlands provide an important link in the Pacific flyway.

\section{Literature Cited}

Abarca, F.J., M.F. Ingraldi, and A. Varela-Romero. 1993. Observations on the desert pupfish (Cyprinodon macularius), Yuma clapper rail (Rallus longirostris yumanensis) and shorebird communities in the Cienega de Santa Clara, Sonora, Mexico. Technical report. Nongame and Endangered Wildlife Program, Arizona Game and Fish, Phoenix, Ariz.

Black, G.F. 1983. Prognosis for water conservation and the development of energy resources at the Salton Sea-Destruction or preservation of this unique ecosystem, p. 363-382. In: V.D. Adams and V.A. Lamarra (eds.). Symposium on the aquatic resources management of the Colorado River Ecosystem. Ann Arbor Science, Ann Arbor, Mich.

Boyle, R. 1996. Life, or death, for the Salton Sea (the plight of California's otherworldly sea). Smithsonian 27:86-96.

Burnett, E., E. Kandl, and F. Croxen. 1993. Cienega de Santa Clara: Geologic and hydrologic comments. U.S. Bureau of Reclamation, Yuma Projects Office, Yuma, Ariz.

Cisneros-Mata, M., G. Montemayor-Lopez, and M. Roman-Rodriquez. 1995. Life history and conservation of Totoaba macdonaldi. Conserv. Biol. 9:806-814.

Congdon, C. and D. Luecke. 1996. Concept paper on Colorado River restoration. Environmental Defense Fund, Boulder, Colo.

Diario Oficial. 1993. Decreto por el que se declara area natural protegida con el caracter de Reserva de la Biosfera, la region conocida como Alto Golfo de California y Delta del Rio Colorado, ubicada en aguas del Golfo de California y los municipios de Mexicali, B.C., del Puerto Peñasco y San Luis Rio Colorado, Sonora, p. 24-28. In: Diario Oficial de la Federacion, Mexico City, Mexico.

Eddleman, W.R. 1989. Biology of the Yuma clapper rail in the Southwestern U.S. and Northwestern Mexico. U.S. Bureau of Reclamation, Yuma Projects Office, Yuma, Ariz.

Ezcurra, E., R.S. Felger, A.D. Russell, and M. Equihua. 1988. Freshwater islands in a desert sand sea: The hydrology, flora, and phytogeography of the Gran Desierto oases of northwestern Mexico. Desert Plants 9(2):35-44, $55-63$.

Fradkin, P.L. 1981. A river no more, the Colorado River and the West. Alfred A. Knopf, New York.

Glenn, E.P., R.S. Felger, A. Burquez, and D.S. Turner. 1992. Cienega de Santa Clara: endangered wetland in the Colorado River Delta, Sonora, Mexico. Natural Resources J. 32:817-824. 
Glenn, E.P., C. Lee, R. Felger, and S. Zengel. 1996. Effects of water management on the wetlands of the Colorado River delta, Mexico. Conserv. Biol. 10:1175-1186.

Glenn, E.P., L. Thompson, J. Riley, and D. Baumgartner. 1995. Salinity effects on growth and evapotranspiration of Typha domingensis Pers. Aquatic Bot. 52:75-91.

Hendrickson, D.A. and A. Varela-Romero. 1989. Conservation status of desert pupfish, Cyprinodon macularius, in Mexico and Arizona. Copeia 1989:478483.

Holburt, M.B. 1982. International problems on the Colorado River. Water Supply \& Mgt. 6:105-114.

Holburt, M.B. 1984. The 1983 high flows on the Colorado River and their aftermath. Water Intl. 9:99-105.

Hotham, R. and H. Ohlendorf. 1989. Contaminants in foods of aquatic birds at Kesterton Reservoir, California, 1985. Archives Environ. Contamination Toxicol. 18:773-786.

Kniffen, F.B. 1931. The primitive cultural landscape of the Colorado delta. Univ. of California Publ. in Geol. 5:43-66.

Lee, C.T. 1994. Mapping wetland dynamics in the lower Colorado River delta using archival LANDSAT MSS satellite imagery. Rpt. U.S. Fish \& Wildlife Serv., Albuquerque, N.M.

Leopold, A. 1949. The green lagoons, p. 150-158. In: Aldo Leopold (ed.). A Sand County almanac. Oxford Univ. Press, New York (reprinted 1966).

Lusk, J. 1993. Selenium in aquatic habitats at Imperial National Wildlife Refuge. MS thesis, Univ. Arizona, Tucson.

Martinez, C. 1994. Selenium levels in selected species of aquatic birds on Imperial National Wildlife Refuge. MS thesis, Univ. Arizona, Tucson

Matsui, M., J.E. Hose, P. Garrahan, and G.A. Jordan. 1992. Developmental defects in fish embryos from Salton Sea, California. Bul. Environ. Contamination Toxicol. 48:914-920.

McDougal, D.T. 1904. Delta and delta vegetation. Bot. Gaz. 38:44-63.

Mellink, E., E. Palacios, and S. Gonzalez. 1997. Non-breeding waterbirds of the delta of the Rio Colorado, Mexico. J. Field Ornithol. 68:113-123.

Morales-Abril, G. 1994. Reserva de la Biosfera Alto Golfo de California y Delta del Rio Colorado. Ecologica 3:26-27.

Morrison, J., S. Postel, and P. Gleick. 1996. The sustainable use of water in the lower Colorado River basin. Pacific Inst. Studies in Dev., Environ. Security, Oakland, Calif.

Ong, C., K. Tanji, R. Dahlgren, G. Smith, and A. Quek. 1995. Water quality and trace element evapoconcentration in evaporation ponds for agricultural waste water disposal. J. Agr. Food Chem. 43:1941-1947.

Payne, J.M., F.A. Reid, and E.C. Gonzalez. 1992. Feasibility study for the possible enhancement of the Colorado delta wetlands, Baja California Norte, Mexico. Report to Ducks Unlimited, Inc. and Ducks Unlimited of Mexico, Sacramento, Calif.

Presser, T. 1994. The Kesterton effect. Environ. Mgt. 18:437-454.

Richardson, J. and J. Carrier. 1992. The Colorado: A river at risk. Westcliffe Pub., Englewood, Colo.

Rusk, M. 1991. Selenium risk to Yuma clapper rails and other marsh birds of the lower Colorado River. MS thesis, Univ. Arizona, Tucson.

Salton Sea Authority. 1997. Salt Sea management project implementation plan. California State Water Resources Control Board, Sacramento.

Setmire, J.G. 1984. Water quality in the New River, Calexico to the Salton Sea,
Imperial County, California. Paper 2212, U.S. Geological Survey, Alexandria, Va.

Skorupa, J. and H. Ohlendorf. 1991. Contaminants in drainage water and avian risk thresholds, p. 345-368. In: A. Dinar and D. Silverman (eds.). The economics and management of water and drainage in agriculture. Kluwer, New York.

Sykes, G. 1937. The Colorado Delta. Carnegie Inst. Washington, Publication No. 460. Tanner, R., J. Garcia, E. Glenn, D. Baumgartner, and J. Riley. 1997. Evapotranspiration of Typha in the Cienega de Santa Clara: water volume requirements and salinity effects. Selenium findings in soil, water, plant and animal tissue with recommendation. Report to U.S. Bureau of Reclamation, Yuma Projects Office, Yuma, Ariz.

Thompson, R.W. 1968. Tidal flat sedimentation on the Colorado River Delta, Northwestern Gulf of California. Memoir 107, Geol. Soc. Amer., Boulder, Colo.

U.S. Bureau of Reclamation. 1975. Final environmental statement, Colorado River Basin salinity control project, title I. U.S. Bureau of Reclamation, Yuma, Ariz.

U.S. Bureau of Reclamation. 1990. Colorado River Basin probable maximum floods Hoover and Glen Canyon Dams. U.S. Bureau of Reclamation, Washington, D.C.

U.S. Geological Survey. 1988. Reconnaissance investigation of water quality, bottom sediment and biota associated with irrigation drainage in the lower Colorado River Valley, Arizona, California, and Nevada, 1986-1987. U.S. Geological Surv., Tucson, Ariz.

Valdes-Casillas, C., O. Hinojosa-Huerta, M. Munoz-Viveros, F. ZamoraArroyo, Y. Carrillo-Guerrero, S. Delgado Garcia, M. Lopez-Camacho, E.P. Glenn, J. Garcia, J. Riley, D. Baumgartner, M. Briggs, C.T. Lee, E. Chavarria-Correa, C. Congdon, and D. Luecke. 1998. Information database and local outreach program for the restoration of the Hardy River wetlands, Lower Colorado River delta, Baja California and Sonora, Mexico. Final report to North American Wetland Conservation Council, U.S. Fish and Wildlife Service. Instituto Tecnologico y de Estudios Superiores de Monterrey (ITESM)-Campus Guaymas, Unidad de Informacion Biogeografica (UIB), Guaymas, Sonora, Mexico.

Velez, O.P., M. Escamilla, and A. Reyes. 1978. En balance de sales del distrito de riego de Mexicali, B.C. Natural Resources J. 18:49-67.

Walker, S. and L. Forrest. 1996. Linking the Salton Sea and the Sea of Cortez with binational riparian corridors. Wing Walkers, San Diego, Calif.

Welsh, D. 1992. Selenium in aquatic habitats at Cibola National Wildlife Refuge. MS thesis, Univ. Arizona, Tucson.

Williams, A. 1983. Cocopa. In: A. Ortiz (ed.). Handbook of North American Indians, vol. 10. Smithsonian Inst., Washington, D.C.

Young, T. and C. Congdon. 1994. Plowing new ground: Using economic incentives to control water pollution from agriculture. Environmental Defense Fund, Boulder, Colo.

Zengel, S.A. and E.P. Glenn. 1996. Presence of the desert pupfish (Cyprinodon macularius) in Cienega de Santa Clara, Mexico, following an extensive drydown. Southwestern Naturalist 41:73-78.

Zengel, S.A., V.J. Meretsky, E.P. Glenn, R.S. Felger, and D. Ortiz. 1995. Cienega de Santa Clara, a remnant wetland in the Rio Colorado delta (Mexico): Vegetation distribution and the effects of water flow reduction. Ecol. Eng. 4:19-36. 